\title{
Signal Transducer and Activator of Transcription 3 (Stat3C) Promotes Myeloid-Derived Suppressor Cell Expansion and Immune Suppression during Lung Tumorigenesis
}

\author{
Lingyan $\mathrm{Wu},{ }^{, \dagger \ddagger}$ Hong $\mathrm{Du},{ }^{\ddagger}$ Yuan $\mathrm{Li},{ }^{\S}$ Peng Qu, ${ }^{* \dagger}$ \\ and Cong Yan*† \\ From the Center for Immunobiology," the Indiana University \\ Simon Cancer Center, ${ }^{\dagger}$ and the Department of Pathology and \\ Laboratory Medicine, ${ }^{\ddagger}$ Indiana University School of Medicine, \\ Indianapolis, Indiana; and the Department of Pathology and \\ Oncology, ${ }^{\Im}$ Cancer Center, Fudan University, Shanghai, China
}

Signal transducer and activator of transcription 3 (Stat3) is a potent transcription factor with diverse biological functions. Overexpression of constitutively active form Stat3C in lung alveolar type II (AT II) epithelial cells in CCSP-rtTA/(tetO) $)_{7}-\mathrm{CMV}$-Stat $3 \mathrm{C}$ bitransgenic mice induces chronic inflammation and lung bronchioalveolar adenocarcinoma. In the present study, the population of $\mathrm{CD11b}^{+} \mathrm{Gr}-\mathrm{1}^{+} \mathrm{my}$ eloid-derived suppressor cells (MDSCs) was significantly increased in lung and blood of doxycyclinetreated bitransgenic mice, but $\mathrm{CD}^{+}$and $\mathrm{CD8}^{+} \mathrm{T}$ cells were decreased. In bronchioalveolar lavage fluid and plasma of doxycycline-treated bitransgenic mice, concentrations of MDSC-stimulating cytokines IL-1 $\beta$, IL-6, IL-10, IL-13, INF- $\gamma$, TNF- $\alpha$, and GM-CSF were significantly increased, which stimulated alveolar monocytes/macrophages to $\mathrm{CD}_{11 b^{+}}$ Gr- $1^{+}$cell conversion in vitro. Phosphorylation of proto-oncogenic intracellular signaling molecules Stat3, Erk1/2, and P38 was significantly increased in $\mathrm{CD11b}^{+} \mathrm{Gr}^{-1^{+}}$cells from lung and blood of doxycycline-treated bitransgenic mice. $\mathrm{CD} 11 b^{+} \mathrm{Gr}^{+} \mathrm{1}^{+}$cells from lung of doxycycline-treated bitransgenic mice strongly inhibited proliferation and function of wild-type $\mathrm{CD}^{+} \mathrm{T}$ cells in vitro. These findings support the concept that persistent activation of Stat3 induces inflammation during lung cancer by promoting MDSC-mediated immune suppression. (Am J Pathol 2011, 179:2131-2141; DOI: 10.1016/j.ajpath.2011.06.028)
We have previously reported that persistent activation of the Stat3 signaling pathway, by overexpressing constitutively active Stat3C, in lung alveolar type II (AT II) epithelial cells directly induces spontaneous bronchioalveolar adenocarcinoma in CCSP-rtTA/(tetO) $)_{7}$-Stat3C bitransgenic mice. ${ }^{1}$ The process is initiated by synthesis and induction of proinflammatory cytokines and chemokines in AT II epithelial cells, triggering heightened levels of inflammatory cell infiltration. Subsequent studies showed that persistent activation of Stat3 in AT II epithelial cells is a common phenomenon in inflammation-induced lung tumor animal models, as demonstrated by matrix metalloproteinase 12 (MMP12) and apoptosis inhibitor 6 (Api6) overexpression bitransgenic mouse models. ${ }^{2-4}$ These findings suggested that Stat3 plays a critical role in mediating inflammation-induced lung adenocarcinoma formation. In a clinical setting, the expression of Stat3 and the genes it induces are increased in human lung adenocarcinoma and in chronic obstructive pulmonary disease, a disease similar in pulmonary impairment to lung cancer. ${ }^{5}$ Both diseases are common in human smokers. A knockin mouse model also shows the enhanced tumorigenic power of the Stat3C molecule in mammary tumors. ${ }^{6}$

Persistent activation of the Stat3 pathway induces bronchioalveolar adenocarcinoma through both nonimmune and immune mechanisms in the CCSP-rtTA/(tetO) $)_{7}$-Stat3C bitransgenic mouse model. ${ }^{1}$ The nonimmune mechanism involves reactivation of lung developmental genes to promote epithelial outgrowth. The immune mechanism is less clear. Recently, myeloid-derived suppressor cells (MDSCs) have been reported to play a critical role in tumor initiation and migration. ${ }^{7-9}$ In mice, MDSCs are characterized as $\mathrm{CD} 11 \mathrm{~b}^{+} \mathrm{Gr}-1^{+}$cells that consist of

\footnotetext{
Supported by grants from the NIH (CA138759 to C.Y. and HL087001 to H.D.). Accepted for publication June 27, 2011.

Address reprint requests to Cong Yan, Ph.D., The Center for Immunobiology, Department of Pathology and Laboratory Medicine, Indiana University School of Medicine, Walther Hall C418, 980 West Walnut St., Indianapolis, IN 46202-5188. E-mail: coyan@iupui.edu.
} 
heterogeneous immature myeloid lineage cells. MDSC expansion has been reported in various spontaneous and tumor-bearing mouse models. 2,3,10 MDSCs can suppress T-cell function to hijack immune surveillance and promote neoplastic processes..$^{7-9,11}$

To further identify the immune mechanism that contributes to Stat3C-induced lung tumorigenesis, CD11 $\mathrm{b}^{+} \mathrm{Gr}-1^{+}$ cells expansion and immunosuppression were investigated in the CCSP-rtTA/(tetO) $)_{7}$-Stat3C mouse model. Here, we report that overexpression of Stat3C in ATII epithelial cells induces the accumulation of $\mathrm{CD} 11 \mathrm{~b}^{+} \mathrm{Gr}-1^{+}$cells in lung and blood of bitransgenic mice. The concentrations of IL$1 \beta$, IL-6, IL-10, IL-13, INF- $\gamma$, TNF- $\alpha$, and GM-CSF that promote MDSC function are highly increased in bronchioalveolar lung lavage fluid (BALF) and blood. Treatment of wild-type alveolar macrophages with BALF from doxycycline-treated bitransgenic mice or MDSC-promoting cytokines shows monocyte/macrophage $\mathrm{CD} 11 \mathrm{~b}^{+} \mathrm{Gr}-1^{+}$cell conversion. Characteristic activation of oncogenic intracellular signaling molecules (eg, Stat3, Erk1/2, p38, and NF$\kappa \mathrm{B}$ ) is observed in $\mathrm{CD} 11 \mathrm{~b}^{+} \mathrm{Gr}-1^{+}$cells from lung and blood. $\mathrm{CD}_{11} \mathrm{~b}^{+} \mathrm{Gr}-1^{+}$cells from Stat3C-induced transgenic mice strongly suppress T-cell proliferation and lymphokine release in both in vitro and in vivo studies. T-regulatory cells are increased in lung. Our findings support the concept that persistent activation of Stat3 induces tumor initiation and progression through promoting $\mathrm{CD} 11 \mathrm{~b}^{+} \mathrm{Gr}-1^{+}$cells expansion and immune suppression.

\section{Materials and Methods}

\section{Animals}

All scientific protocols involving the use of animals were approved by the Institutional Animal Care and Use Committee (IACUC) of Indiana University School of Medicine and followed guidelines established by the Panel on Euthanasia of the American Veterinary Medical Association. Protocols involving the use of recombinant DNA or biohazardous materials were reviewed by the Biosafety Committee of Indiana University School of Medicine and followed guidelines established by the National Institutes of Health. Animals were housed under IACUC-approved conditions in a secured animal facility at Indiana University School of Medicine and were regularly screened for common pathogens. For experiments involving animal sacrifice, $\mathrm{CO}_{2}$ narcosis was used, to minimize animal discomfort.

\section{Flow Cytometry}

Single-cell preparation from bone marrow, spleen, blood, and lung was performed as described previously. ${ }^{12}$ Cells from various organs in fluorescence-activated cell sorting buffer were stained with cell surface markers. Anti-CD4, anti-CD8, anti-CD11b, and anti-Ly6G were purchased from eBioscience (San Diego, CA). Ly6C antibody and anti-iNOS antibody were purchased from BD Biosciences (San Jose, CA). Anti-S100A8/A9 antibody was purchased from Santa Cruz Biotechnology (Santa Cruz, CA). AntiFlag polyclonal antibody (F7425) was purchased from Sigma-Aldrich (St. Louis, MO).
For measurement of intracellular signaling molecules in ATII epithelial cells and MDSCs, cell suspensions from lung and blood of doxycycline-treated or untreated CCSP-rtTA/ (tetO) 7 -CMV-Stat3C bitransgenic mice were labeled with anti-SP-C antibody (FL-197; Santa Cruz Biotechnology) or anti-CD11b and GR-1 surface antibodies and then were fixed with $2 \%$ formaldehyde. Fixation samples were resuspended in methanol at a final concentration of $90 \%$ for 30 minutes on ice, and then labeled with the phospho-specific antibodies at $4^{\circ} \mathrm{C}$ overnight. Anti-phospho-P44/42 (Erk1/2) antibody, anti-phospho-P38 antibody, anti-phospho-NF$\kappa \mathrm{B}$ antibody, and anti-phospho-Stat3 antibody were purchased from Cell Signaling Technology (Danvers, MA). Intracellular Foxp3 staining was performed according to the manufacturer's instructions (eBioscience).

Cells were analyzed on an LSR II flow cytometer (BD Biosciences). Data were analyzed using FACStation software (BD CellQuest Pro version 5.2.1, BD Biosciences). The total number of positive cells was calculated (gated viable cells). Isotype controls were included in all experiments. Quadrants were assigned using isotype controls.

\section{Cytokine Measurement by ELISA}

The expression levels of IFN- $\gamma, \mathrm{IL}-1 \beta, \mathrm{IL}-4, \mathrm{IL}-6, \mathrm{IL}-10$, IL-13, TNF- $\alpha$, G-CSF, M-CSF, and GM-CSF in BALF and blood plasma from doxycycline-treated or untreated CCSP-rtTA/(tetO) $)_{7}-\mathrm{CMV}$-Stat3C bitransgenic mice were measured using enzyme-linked immunosorbent assay (ELISA) kits according to the manufacturer's instructions (R\&D Systems, Minneapolis, MN).

\section{Wild-Type Macrophage Treatment by BALF or Cytokines in Vitro}

BALF was collected from lung of doxycycline-treated or untreated CCSP-rtTA/(tetO) $)_{7}-\mathrm{CMV}$-Stat3C bitransgenic mice. Macrophages were purified from wild-type lung lavage, and resuspended in RPMI 1640 medium containing 10\% fetal bovine serum. Purified macrophages were cultured with BALF or GM-CSF $(0.1 \mu \mathrm{g} / \mathrm{mL}), \mathrm{IL}-1 \beta(0.1 \mu \mathrm{g} / \mathrm{mL})$, IL-6 (0.1 $\mu \mathrm{g} / \mathrm{mL}), \mathrm{IL}-10(0.1 \mu \mathrm{g} / \mathrm{mL})$, TNF- $\alpha(0.1 \mu \mathrm{g} / \mathrm{mL})$, and VEGF $(0.1 \mu \mathrm{g} / \mathrm{mL})$ for 3 days. After incubation, cells were harvested, and labeled with anti-CD11b and anti-GR-1 antibodies, and analyzed by flow cytometry.

\section{MDSC Immunosuppression in Vitro Assay}

To purify $\mathrm{CD}^{+}{ }^{+} \mathrm{T}$ cells, erythrocyte-depleted wild-type splenocytes were stained with anti-CD4 microbeads and then passed over a mass spectrometry column according to the manufacturer's instructions (Miltenyi Biotec, Auburn, CA). To purify CD11 ${ }^{+} \mathrm{Gr}-1^{+}$MDSCs, lung cells were placed in anti-CD11b Ab-coated culture dishes and incubated for 3 hours at $37^{\circ} \mathrm{C}$ in $5 \% \mathrm{CO}_{2}$. The next day, cells were gently washed with PBS to remove the plastic nonadherent cells. Adherent cells were incubated with biotin-labeled primary GR-1 antibody for 20 minutes, followed by 20 minutes incubation of anti-biotin secondary antibody beads in PBS. Labeled cells were selected on a 
mass spectrometry column using magnetic-activated cell sorting technology (Miltenyi Biotech).

The sorted $\mathrm{CD}^{+}{ }^{+} \mathrm{T}$ cells from wild-type spleen were stained in PBS containing $1 \mu \mathrm{mol} / \mathrm{L}$ carboxyfluorescein diacetate succinimidyl diester (Molecular Probes, Eugene, $\mathrm{OR}$ ) at $37^{\circ} \mathrm{C}$ for 10 minutes, pelleted, and resuspended in 100\% fetal bovine serum for 40 minutes. CD4 ${ }^{+}$ T cells were washed twice in PBS and cultured in 96-well flat-bottom plates coated with anti-CD3 mAb $(2 \mu \mathrm{g} / \mathrm{mL})$ and anti-CD28 mAb $(5 \mu \mathrm{g} / \mathrm{mL})$. Purified MDSCs from lung of doxycycline-treated or untreated CCSP-rtTA/(tetO) ${ }_{7-}$ CMV-Stat3C bitransgenic mice were cocultured for 4 days. Cells were harvested, stained with allophycocyanin-labeled anti-CD4 mAb (eBioscience), and analyzed by flow cytometry (BD Biosciences). For the CD69 expression or annexin $\mathrm{V}$ assay, MDSCs and $\mathrm{CD} 4^{+} \mathrm{T}$ cells were cocultured in 96-well plates coated with anti-CD3 $\mathrm{mAb}(2 \mu \mathrm{g} / \mathrm{mL})$ and anti-CD28 mAb $(5 \mu \mathrm{g} / \mathrm{mL})$ for 48 hours. Cells were harvested, stained with anti-CD4 mAb, anti-CD69 mAb (eBioscience), or annexin $\mathrm{V}$, and analyzed by flow cytometry (BD Biosciences). The concentrations of IL-2 and IL-4 in the culture medium were detected by ELISA according to the manufacturer's instructions (R\&D Systems, Minneapolis, MN).

\section{T-Cell Assay of Bitransgenic Mice in Vivo}

To measure T-cell proliferation and function in vivo, the sorted $\mathrm{CD}^{+}{ }^{+} \mathrm{T}$ cells from spleen of 9-month doxycyclinetreated or untreated CCSP-rtTA/(tetO) ${ }_{7}-\mathrm{CMV}-\mathrm{Stat} 3 \mathrm{C}$ bitransgenic mice were labeled with $1 \mu \mathrm{mol} / \mathrm{L}$ carboxyfluorescein diacetate succinimidyl diester and cultured in 96-well flat-bottom plates coated with anti-CD3 mAb $(2 \mu \mathrm{g} /$ $\mathrm{mL})$ and anti-CD28 mAb (5 $\mu \mathrm{g} / \mathrm{mL})$ for 4 days. Cells were harvested, stained with allophycocyanin-labeled anti-CD4 $\mathrm{mAb}$ (eBioscience), and analyzed by flow cytometry (BD Biosciences). For CD69 expression assay, the sorted CD4 ${ }^{+}$ T cells were cultured in 96-well plates coated with anti-CD3 $(2 \mu \mathrm{g} / \mathrm{mL})$ and anti-CD28 mAb (5 $\mu \mathrm{g} / \mathrm{mL})$. After 48 hours, cells were harvested, and stained with allophycocyaninlabeled anti-CD4 mAb and PE-labeled anti-CD69 mAb (eBioscience), and analyzed by flow cytometry (BD Biosciences). The concentrations of IL-2 and IL-4 in the culture medium were detected by ELISA.

\section{Arginase Activity}

Arginase activity was measured in BALF cell lysates. ${ }^{13}$ Briefly, cells were lysed for 30 minutes at room temperature with $50 \mu \mathrm{L}$ of $0.1 \%$ Triton X-100 PBS containing $5 \mu \mathrm{g}$ pepstatin, $5 \mu \mathrm{g}$ aprotinin, and $5 \mu \mathrm{g}$ antipain protease inhibitors. Subsequently, $50 \mu \mathrm{L}$ of $10 \mathrm{mmol} / \mathrm{L} \mathrm{MnCl}_{2}$ and $50 \mu \mathrm{L}$ of $50 \mathrm{mmol} / \mathrm{L}$ Tris-HCl (PH7.5) were added, and the enzyme was activated by heating for 10 minutes at $56^{\circ} \mathrm{C}$. Arginine hydrolysis $(100 \mu \mathrm{L}$ ) was conducted by incubating the lysate with $100 \mu \mathrm{L}$ of $0.5 \mathrm{~mol} / \mathrm{L}$ L-arginine $(\mathrm{pH}$ 9.7) at $37^{\circ} \mathrm{C}$ for 60 to 120 minutes. The reaction was stopped with $400 \mu \mathrm{L}$ of $\mathrm{H}_{2} \mathrm{SO}_{4}(96 \%) / \mathrm{H}_{3} \mathrm{PO}_{4}(85 \%) / \mathrm{H}_{2} \mathrm{O}(1: 3: 7$, $\mathrm{v} / \mathrm{v} / \mathrm{v})$. The urea concentration was measured at $540 \mathrm{~nm}$ after addition of $25 \mu \mathrm{L}$ of $9 \% \alpha$-isonitrosopropiophenone (dissolved in $100 \%$ ethanol), followed by heating at $95^{\circ} \mathrm{C}$
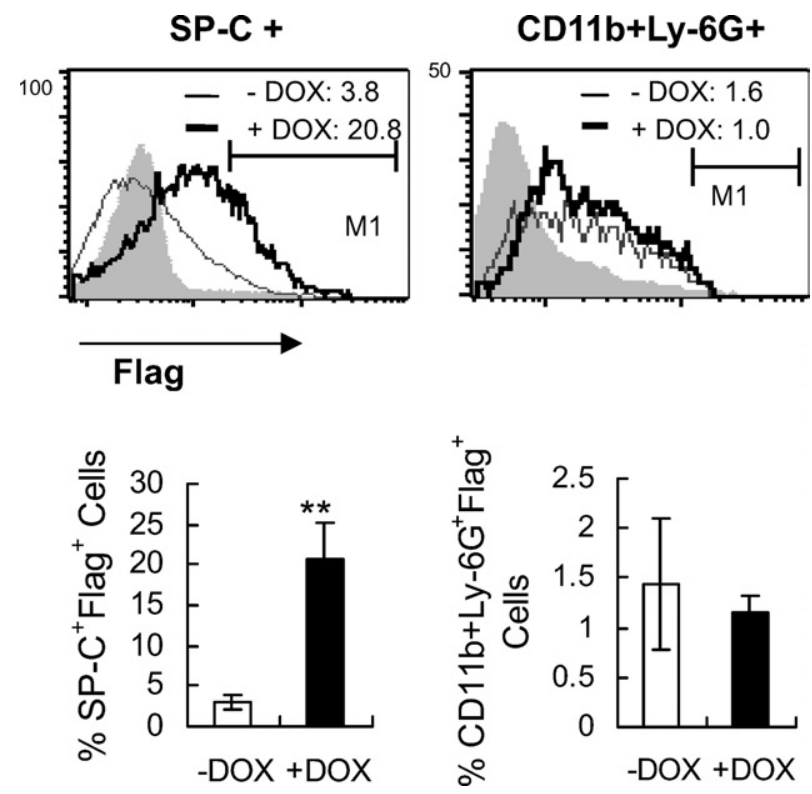

Figure 1. Expression of the Stat3C-Flag fusion protein in AT II epithelial cells from lung of 3-month doxycycline-treated (+DOX) and untreated (-DOX) bitransgenic mice as determined by flow cytometry. Cells were double-labeled with anti-Flag and anti-SP-C antibodies (AT II marker). CD11b and Ly-6G are myeloid cell markers and serve as the negative control. Shaded areas indicate isotype control. M1 indicated a histogram marker excluding isotype negative control. For quantification, values are reported as means $\pm \mathrm{SD}(n=4)$. **ak $P<0.01$.

for 45 minutes and 10 minutes in darkness. One unit of enzyme activity is defined as the amount of enzyme that catalyzes the formation of $1 \mu \mathrm{mol}$ urea per minute.

\section{Statistical Analysis}

Data are reported as means \pm SD. A paired Student's $t$-test or analysis of variance was used to evaluate the significance of the differences. Statistical significance was set at a level of $P<0.05$.

\section{Results}

\section{Stat3C Overexpression in AT II Epithelial Cells}

A doxycycline-inducible bitransgenic mouse model was generated to specifically direct Stat3C expression in lung epithelial cells as described previously, ${ }^{1}$ in which a Flag sequence was added at the $\mathrm{C}$ terminus of Stat $3 \mathrm{C}$ cDNA to distinguish it from endogenous Stat3. To assess whether Stat3-Flag fusion protein is induced in AT II epithelial cells, flow cytometry analysis was performed to double-label lung single cells using anti-SP-C (AT II epithelial cell marker) and anti-Flag antibodies. Expression of the Stat3-Flag fusion protein was readily detected in $\mathrm{SP}^{-\mathrm{C}^{+}}$AT II epithelial cells in doxycycline-treated CCSPrtTA/(tetO) $)_{7}-\mathrm{CMV}$-Stat3C bitransgenic mice, but not in alveolar $\mathrm{CD}_{11 \mathrm{~b}^{+}} \mathrm{Ly}_{6 \mathrm{G}}{ }^{+}$myeloid cells (Figure 1). No Stat3C-Flag fusion protein was detected in SP-C ${ }^{+}$AT II epithelial cells from doxycycline-untreated bitransgenic mice. This observation confirms our previous observation, based on immunohistochemical staining. ${ }^{1}$ 


\section{Stat3C Overexpression Induces Accumulation of $\mathrm{CD} 11 \mathrm{~b}^{+} \mathrm{Gr}-1^{+}$Cells}

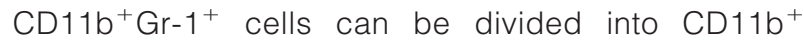
Ly $6 G^{+}$and CD $11 b^{+}$Ly6C $^{+}$subpopulations. ${ }^{14}$ To investigate whether persistent activation of the Stat3 pathway promotes $\mathrm{CD} 11 \mathrm{~b}^{+} \mathrm{Gr}-1^{+}$cell expansion in various compartments, cells from bone marrow, spleen, peripheral blood, and lung were isolated from 3-, 6-, and 9-month doxycycline-treated or untreated CCSP-rtTA/(tetO) $)_{7}-\mathrm{CMV}-$ Stat3C bitransgenic mice and stained with fluorochrome-conjugated anti-mouse CD11b and Ly6G (or Ly6C) antibodies for flow cytometry analysis. This methodology was chosen because inflammatory cells begin to be detectable at 3 months (prior tumor formation) and extend to 9 months (after tumor formation)

A
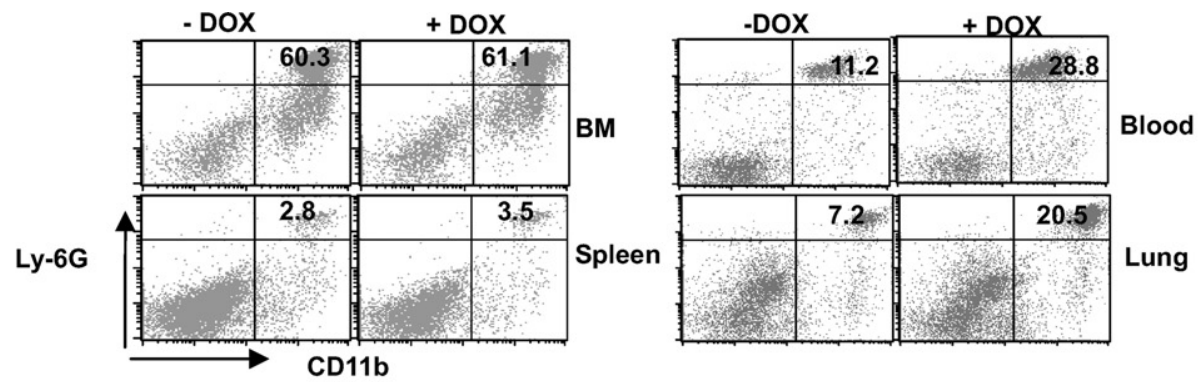

B
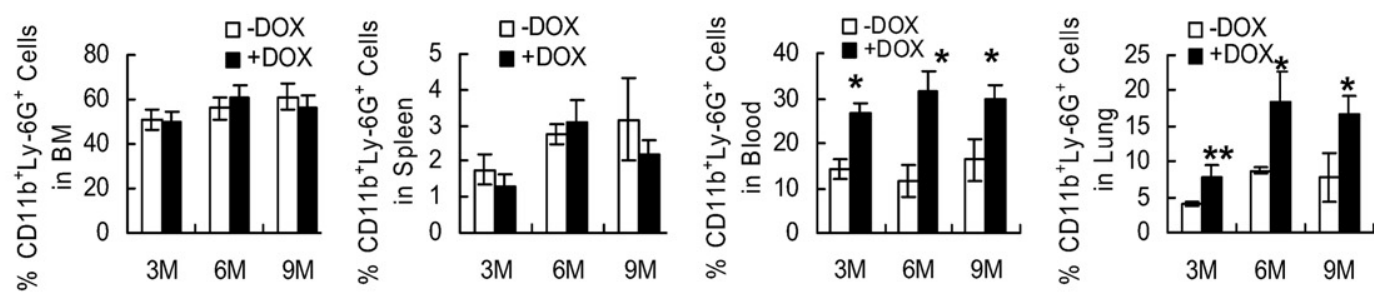

C - DOX + DOX

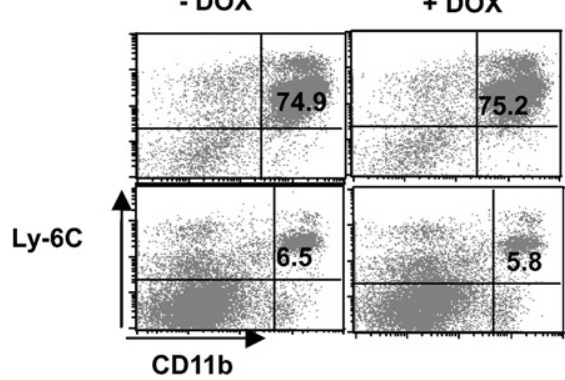

BM
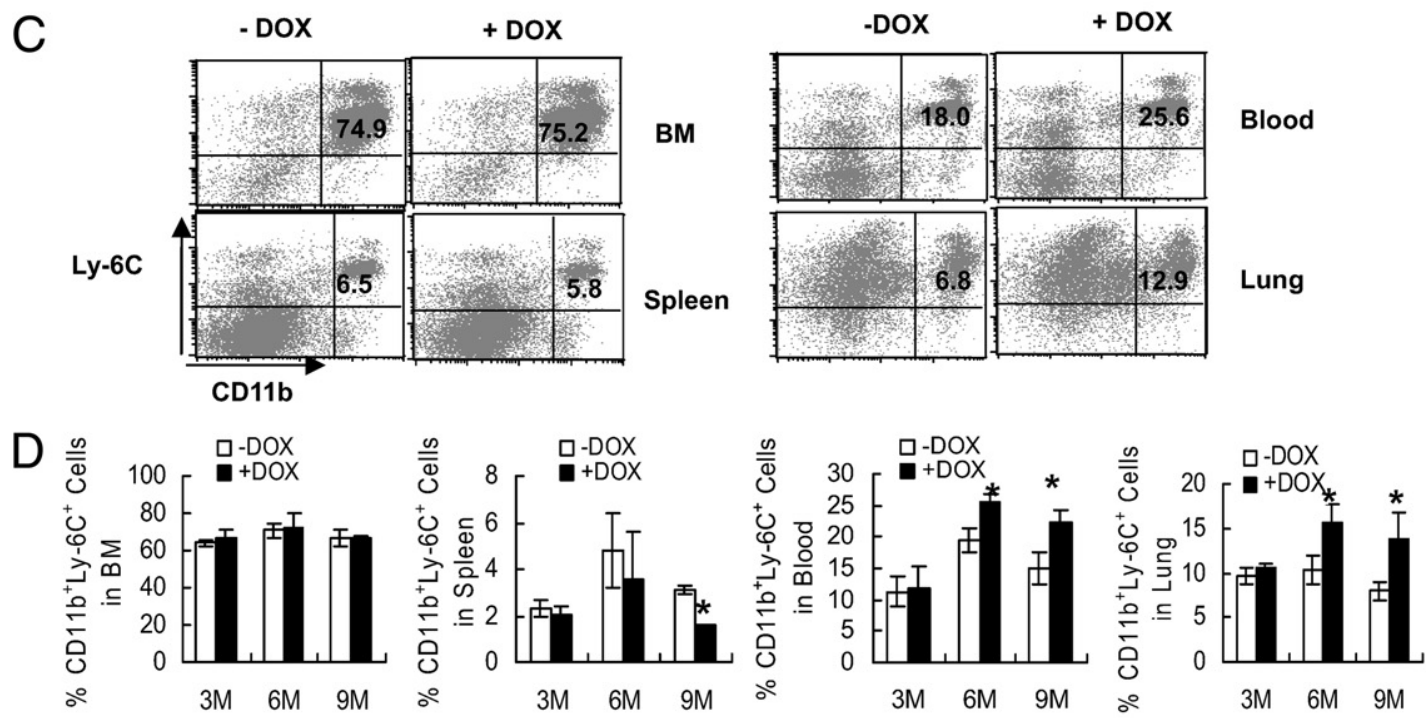

E
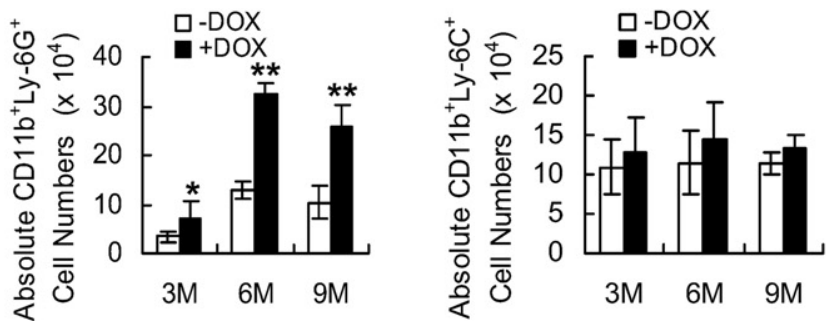

Figure 2. The MDSC population in bone marrow, spleen, blood, and lung of CCSP-rtTA/(tetO) 7 -CMV-Stat3C bitransgenic mice. A: Representative dot-plot of $\mathrm{CD}_{11 \mathrm{~b}}{ }^{+} \mathrm{Ly}_{6 \mathrm{G}}{ }^{+}$cell populations from 6-month doxycycline-treated (+DOX) and untreated ( $\left.-\mathrm{DOX}\right)$ bitransgenic mice. B: Percentages of the CD11b ${ }^{+} \mathrm{Ly}_{6 \mathrm{G}}{ }^{+}$cell population in bone marrow (BM), spleen, blood, and lung from 3-, 6-, and 9-month (3M, 6M, and 9M) +DOX and -DOX bitransgenic mice, as analyzed by flow cytometry. C: Representative dot-plot of CD $11 b^{+} \mathrm{Ly}_{6 \mathrm{C}^{+}}$cell population from 6 -month +DOX and - DOX bitransgenic mice. D: Percentages of the CD $11 \mathrm{~b}^{+}$Ly6C ${ }^{+}$ cell population in bone marrow (BM), spleen, lung, and blood from 3-, 6-, and 9-month +DOX and -DOX bitransgenic mice were analyzed by flow cytometry. E: The absolute numbers of $\mathrm{CD} 11 \mathrm{~b}^{+} \mathrm{Ly}_{6 \mathrm{G}}{ }^{+}$and $\mathrm{CD} 11 \mathrm{~b}^{+} \mathrm{Ly}_{6 \mathrm{C}}+$ cell populations in lung from 3-, 6-, and 9-month +DOX and $-\mathrm{DOX}$ bitransgenic mice were analyzed by flow cytometry. Data are reported as means \pm SD of at least six independent animals $(n>6) .{ }^{*} P<0.05 ;{ }^{* * *} P<0.01$ 
of doxycycline treatment in bitransgenic mice, as we have reported previously. ${ }^{1}$

Compared with doxycycline-untreated bitransgenic mice, the percentages of the $\mathrm{CD} 11 \mathrm{~b}^{+} \mathrm{Ly}_{6 \mathrm{G}}{ }^{+}$cell population were steadily increased in blood and lung of doxycycline-treated bitransgenic mice (Figure 2, A and B), but not in bone marrow and spleen. The absolute number of $\mathrm{CD}_{11 \mathrm{~b}^{+} \mathrm{Ly} 6 \mathrm{G}^{+}}$cells was also significantly increased in lung of doxycycline-treated bitransgenic mice. compared with the untreated bitransgenic mice (Figure 2E). The absolute number of $\mathrm{CD} 11 \mathrm{~b}^{+} \mathrm{Ly}_{6 \mathrm{G}}{ }^{+}$cells was unchanged in bone marrow and spleen between doxycycline-treated and untreated bitransgenic mice (data not shown). We further investigated $\mathrm{CD} 11 \mathrm{~b}^{+} \mathrm{Ly}_{6 \mathrm{C}}{ }^{+}$cells in bitransgenic mice. Compared with doxycycline-untreated bitransgenic mice, the percentages of the $\mathrm{CD} 11 \mathrm{~b}^{+} \mathrm{Ly}_{\mathrm{C}} \mathrm{C}^{+}$cell population were increased in blood and lung of doxycycline-treated bitransgenic mice (Figure 2, C and D), but not in bone marrow and spleen. The absolute number of $\mathrm{CD} 11 \mathrm{~b}^{+} \mathrm{Ly}_{6 \mathrm{C}^{+}}$cells was unchanged in doxycycline-treated bitransgenic mice, compared with untreated bitransgenic mice (Figure 2E). These observations demonstrate that Stat3C overexpression in AT II epithelial cells causes inflammatory cell expansion in lung and blood, but not in bone marrow and spleen.

\section{T-Cell Proliferation in CCSP-rtTA((tetO) $)_{7}-C M V$ - Stat3C Bitransgenic Mice}

T-cell populations were also investigated in the samples from bone marrow, spleen, peripheral blood, and lung, using fluorochrome-conjugated anti-mouse CD4 and CD8 an- tibodies for flow cytometry analysis. In contrast to myeloid cells, the percentage numbers of $\mathrm{CD} 4^{+}$cells in spleen, blood, and lung were reduced in doxycycline-treated CCSP-rtTA/(tetO) $)_{7}$-CMV-Stat3C bitransgenic mice, compared with the untreated mice, but there was no significant change in $\mathrm{CD}^{+} \mathrm{T}$ cells except in lung of 6- and 9-month and in blood of 6-month doxycycline-treated bitransgenic mice (Figure $3, \mathrm{~A}$ and $\mathrm{B}$ ). Of note, $\mathrm{CD} 4^{+} \mathrm{T}$ regulatory cells were increased in lung of doxycycline-treated bitransgenic mice, compared with the untreated controls (Figure 3C).

\section{Up-Regulation of MDSC-Stimulating Cytokines in CCSP-rtTA (tetO) $)_{7}-C M V$-Stat3C Bitransgenic Mice}

To elucidate the mechanisms by which $\mathrm{CD} 11 \mathrm{~b}^{+} \mathrm{Gr}-1^{+}$ cells are expanded in lung and blood of bitransgenic mice, cytokines that are known to stimulate MDSC expansion were measured in BALF and blood plasma by ELISA. The concentrations of IFN- $\gamma$, IL-1 $\beta$, IL-6, IL-10, IL-13, TNF- $\alpha$, and GM-CSF in BALF of 1-, 3-, 6-, and 9-month doxycycline-treated mice were steadily increased, but M-CSF and G-CSF showed no change, compared with those in untreated bitransgenic mice (Figure 4A). The plasma concentrations of IFN- $\gamma$, IL-1 $\beta$, IL-6, IL-10, IL-13, TNF- $\alpha$, M-CSF, and GM-CSF in 1-, 3-, 6-, and 9-month doxycycline-treated mice were also steadily increased, but G-CSF was decreased, compared with untreated mice (Figure 4B). These cytokines have been recently demonstrated to be important for MDSC accumulation and tumorigenesis. ${ }^{15,16}$ As we have reported previously, mRNA syntheses of these
A
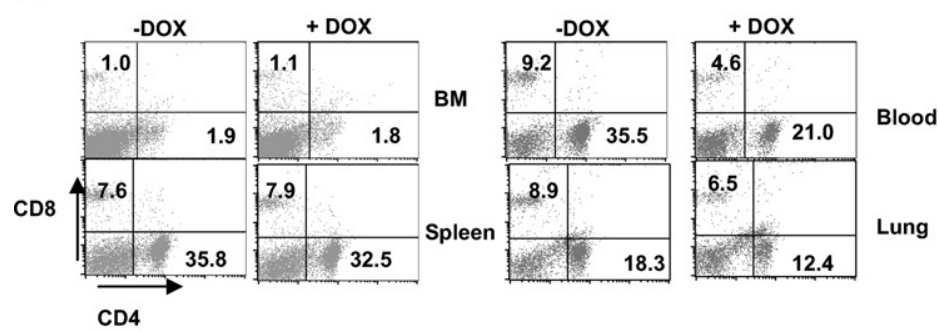

C

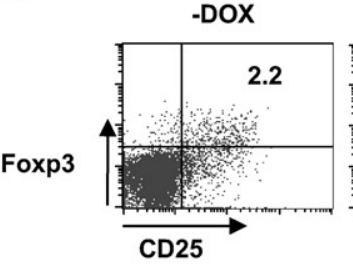

Lung

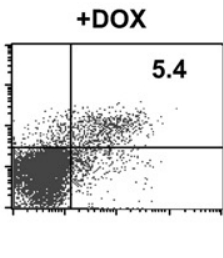

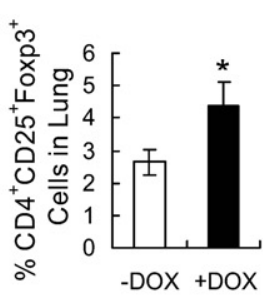

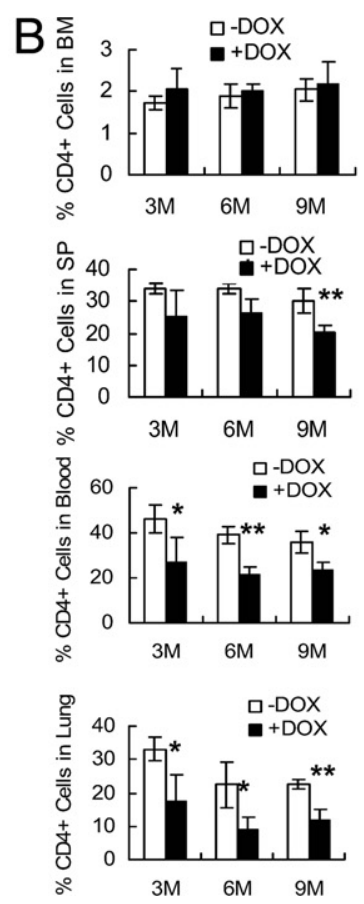

Figure 3. T-cell populations in bone marrow, spleen, blood, and lung of CCSP-rtTA/(tetO) $)_{7}$-CMV-Stat3C bitransgenic mice. A: Representative dot-plot of CD $4^{+}$and $\mathrm{CD}^{+}$cell populations from 6 -month + DOX and -DOX bitransgenic mice is presented. B: The percentages of CD $4^{+}$and CD8 ${ }^{+}$cell populations in bone marrow (BM), spleen, blood, and lung from 3-, 6-, and 9-month +DOX and -DOX bitransgenic mice were analyzed by flow cytometry. C: Representative dot-plot CD $4^{+} \mathrm{CD} 25^{+}$Foxp $3^{+}$ cell populations from lung of $6-$ month + DOX and - DOX mice and analysis by flow cytometry. Data are reported as means \pm SD of at least six independent animals $(n>6)$. -DOX, doxycycline-untreated bitransgenic mice; +DOX, doxycycline-treated bitransgenic mice. ${ }^{*} P<0.05 ;{ }^{* *} P<0.01$. 
A
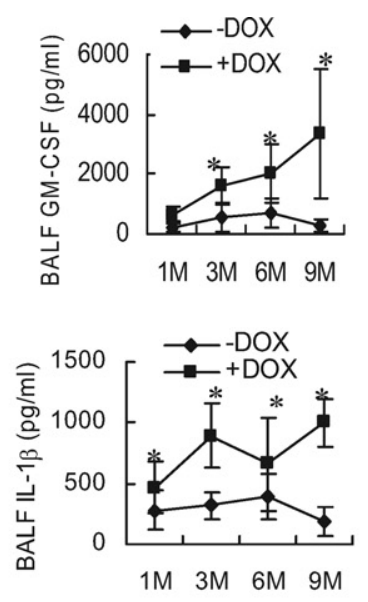
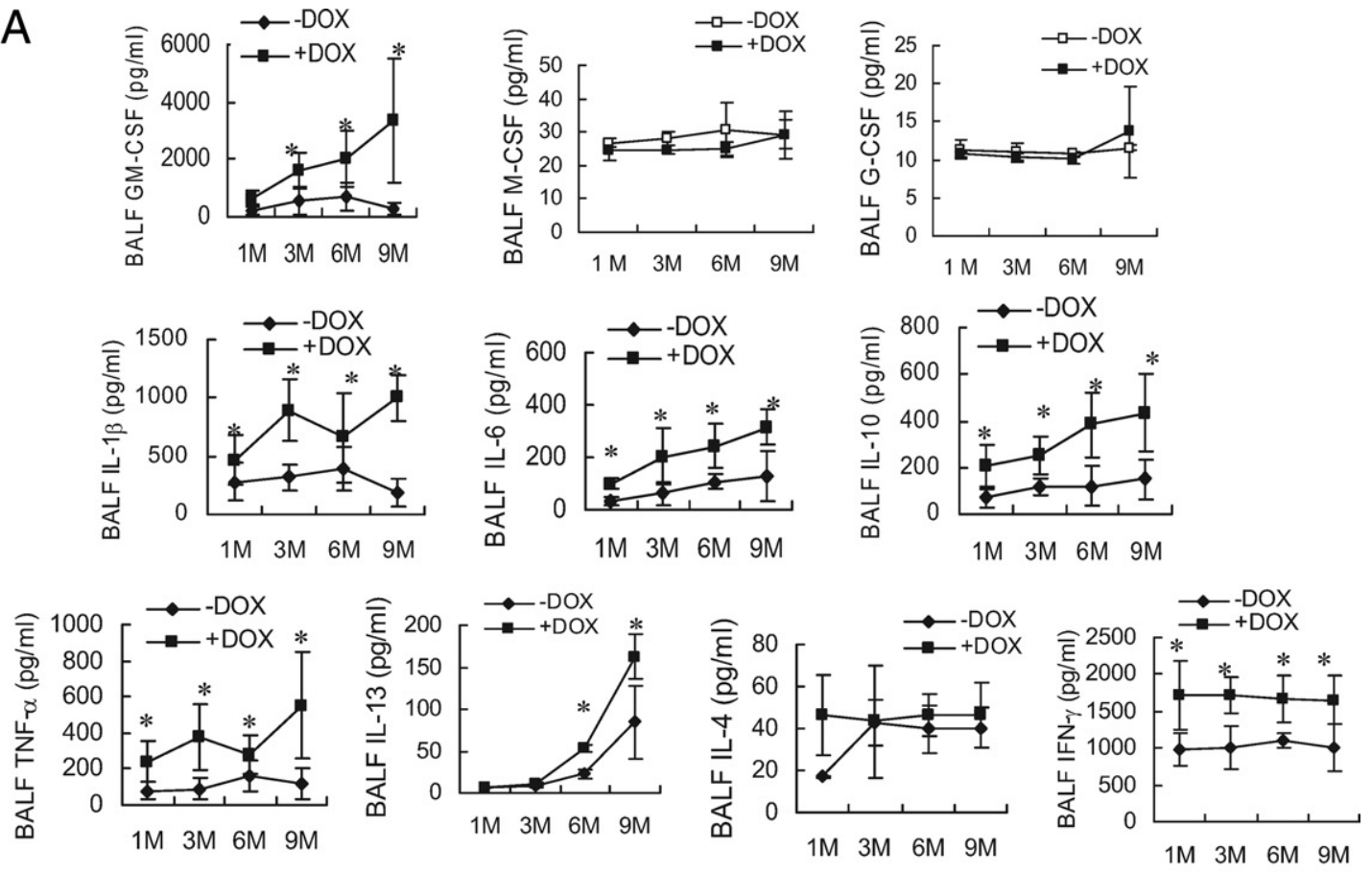

B
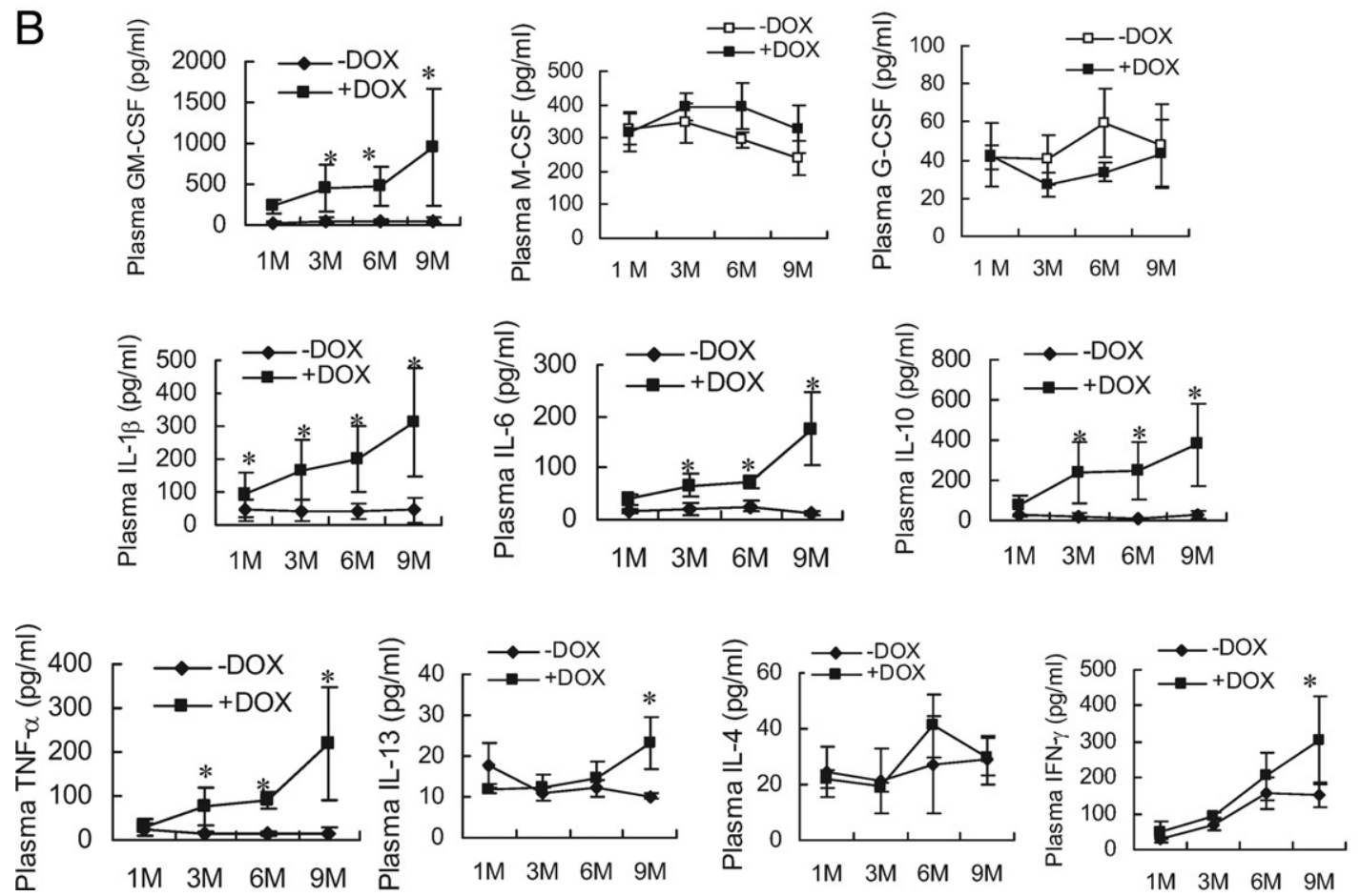

Figure 4. Concentrations of MDSC-stimulating cytokines in BALF and plasma of CCSP-rtTA/(tetO) $)_{7}$-CMV-Stat3C bitransgenic mice. A: The concentrations of IL- $1 \beta$, IL-6, IL-10, TNF- $\alpha$, G-CSF, M-CSF, and GM-CSF in BALF of lung from bitransgenic mice that were treated or untreated with doxycycline for 1, 3, 6, and 9 months $(1 \mathrm{M}, 3 \mathrm{M}, 6 \mathrm{M}$, and $9 \mathrm{M})$, as determined by ELISA $(n=6)$. B: The concentrations of IL- $1 \beta$, IL- 6 , IL- 10 , TNF- $\alpha$, G-CSF, M-CSF, and GM-CSF in plasma of bitransgenic mice that were treated or untreated with doxycycline for $1,3,6$, or 9 months, as determined by ELISA $(n=6)$. - DOX, doxycycline-untreated bitransgenic mice; + DOX, doxycycline-treated bitransgenic mice. ${ }^{*} P<0.05$.

cytokines are up-regulated in AT II epithelial cells of bitransgenic mice at a very early stage ( 1 month of doxycycline treatment). ${ }^{1}$ It is likely, therefore, that Stat3C-induced $\mathrm{CD} 11 \mathrm{~b}^{+} \mathrm{Gr}-1^{+}$cell expansion is initiated by synthesis and secretion of these cytokines from AT II epithelial cells into BALF and blood.

\section{Macrophage to $C D 11 b^{+} L_{6} 6 G^{+}$Conversion by BALF and Cytokines}

To study how the cytokine change influences CD11 $b^{+} \mathrm{Ly}_{6 \mathrm{G}^{+}}$cells in lung, BALF from doxycyclinetreated or untreated CCSP-rtTA/(tetO) $)_{7}-\mathrm{CMV}-\mathrm{Stat} 3 \mathrm{C}$ bi- 
A

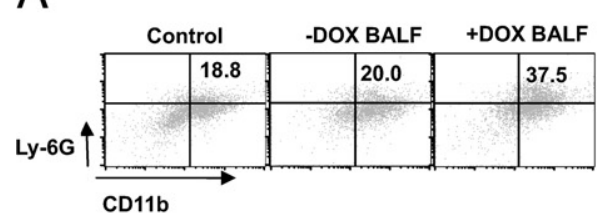

C<smiles></smiles>

Total

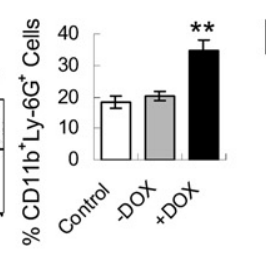

B

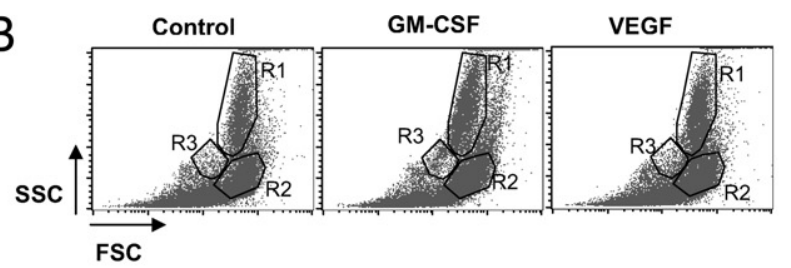

$\mathrm{D}$ Control
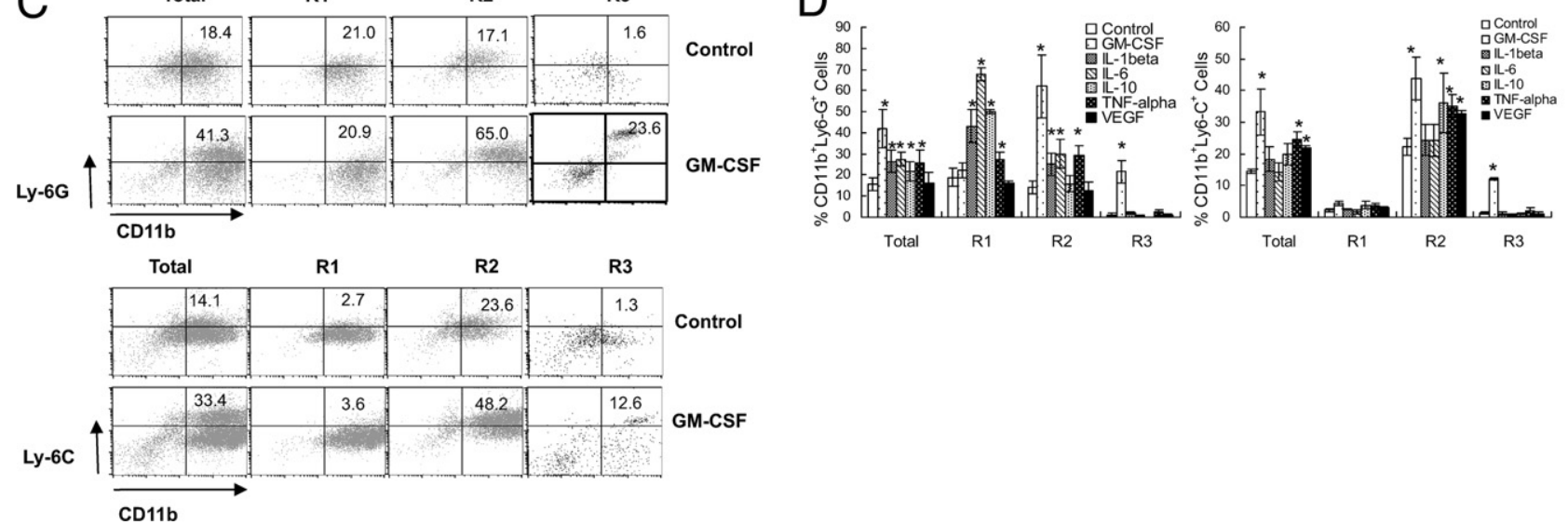

Figure 5. Conversion of $\mathrm{CD} 11 \mathrm{~b}^{+} \mathrm{GR}-1^{+}$cells from BALF cells. A: Wild-type alveolar macrophages were incubated with BALF from doxycycline-treated or untreated bitransgenic mice for 3 days. After incubation, CD $11 \mathrm{~b}^{+} \mathrm{GR}-1^{+}$cells were analyzed by flow cytometry. Representative dot-plots and quantitative analyses of three independent experiments are presented. Control, PBS; -DOX, BALF from doxycycline-untreated bitransgenic mice; + DOX, BALF from doxycycline-treated bitransgenic mice. ${ }^{* *} P<0.01$. B: Wild-type alveolar macrophages were incubated with PBS, GM-CSF, and VEGF for 3 days. $\mathrm{CD} 11 \mathrm{~b}^{+} \mathrm{GR}-1^{+}$cells were analyzed after incubation by flow cytometry in R1, R2, and R3 gated areas. A representative analysis is presented. C: Wild-type alveolar macrophages were incubated with PBS, GM-CSF, IL- $1 \beta$, IL-6, IL-10, TNF- $\alpha$, and VEGF for 3 days. After incubation, CD $11 b^{+}$GR- $1^{+}$cells were analyzed by flow cytometry in R1, R2, and R3 gated areas. Data are reported as means \pm SD from three independent experiments. ${ }^{*} P<0.05$.

transgenic mice was incubated with isolated wild-type alveolar monocytes/macrophages in vitro. After 3 days incubation, the $\mathrm{CD} 11 \mathrm{~b}^{+} \mathrm{Ly}_{6 \mathrm{G}}{ }^{+}$immature population was increased to $37.5 \%$ in doxycycline-treated mice, compared with $18.8 \%$ in untreated mice (Figure 5A), suggesting reverse conversion of differentiated alveolar monocytes/macrophages back to the immature stage. To test whether inflammatory cytokines in BALF (Figure 4) are responsible for this conversion, GM-CSF, IL-1 $\beta$, IL-6, IL-10, and TNF- $\alpha$ were incubated with isolated wild-type alveolar monocytes/macrophages in vitro. VEGF was also included for testing. Based on our observations, CD11 b ${ }^{+}$Ly6G $G^{+}$cells in lung were heterogeneous populations and could be divided into three gating areas (Figure 5B). GM-CSF was able to stimulate the $\mathrm{CD} 11 \mathrm{~b}^{+} \mathrm{Ly}_{6 \mathrm{G}}{ }^{+}$cell conversion in the $\mathrm{R} 2$ and $\mathrm{R} 3$ areas. IL-1 $\beta, \mathrm{IL}-6, \mathrm{TNF}-\alpha$, were able to stimulate the $\mathrm{CD} 11 \mathrm{~b}^{+} \mathrm{Ly}_{6 \mathrm{G}}{ }^{+}$cell conversion in the $\mathrm{R} 1$ and $\mathrm{R} 2$ areas. IL-10 was able to stimulate the CD11b ${ }^{+} \mathrm{Ly}_{6 \mathrm{G}}{ }^{+}$cell conversion only in the $\mathrm{R} 1$ area. VEGF lacked the ability to stimulate CD11b ${ }^{+} \mathrm{Ly}_{6 \mathrm{G}}{ }^{+}$cell conversion (Figure 5, C and D). In CD11 b ${ }^{+}$Ly6C $^{+}$cells, GM-CSF was able to stimulate the CD11 $b^{+}{\text {Ly } 6 C^{+}}^{+}$cell conversion in the R2 and $\mathrm{R} 3$ areas. IL-10, TNF- $\alpha$, and VEGF were able to stimulate the CD11 $b^{+} \mathrm{Ly}_{6 C^{+}}$cell conversion in the R2 area (Figure 5, C and D). These observations suggest that different cytokines have differential abilities to stimulate formation of different $\mathrm{CD} 11 \mathrm{~b}^{+} \mathrm{Ly}_{6 G^{+}}$or
CD11b ${ }^{+}$Ly6C $^{+}$subpopulations under the tumor microenvironment.

\section{Intrinsic Change of CD11b ${ }^{+} \mathrm{Ly}_{6} \mathrm{G}^{+}$in CCSP- rtTAV(tetO) ${ }_{7}-C M V$-Stat3C Bitransgenic Mice}

To further investigate how the microenvironment change affects properties of CD11b ${ }^{+} \mathrm{Ly}_{6 \mathrm{G}}{ }^{+}$cells, we investigated the activation of intracellular signaling molecules in CD11 b ${ }^{+} \mathrm{Ly}_{6 \mathrm{G}}{ }^{+}$cells. Intranuclear stain-

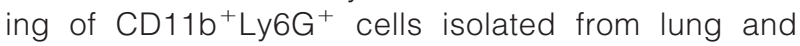
blood of 6-month doxycycline-treated or untreated CCSP-rtTA/(tetO) $)_{7}-\mathrm{CMV}-$ Stat3C bitransgenic mice was analyzed with anti-CD11b/anti-Ly6G antibodies coupled with anti-phospho-Stat3, anti-phospho-Erk1/2, anti-phospho-NF- $\kappa$ B, or anti-phospho-p38 antibody. Flow cytometry of costained cells revealed increased activation of oncogenic pStat3, pErk1/2, pNF- $\kappa$ B, and pP38 in doxycycline-treated CD11b ${ }^{+}$Ly6G $^{+}$cells, compared with untreated cells in bitransgenic mice (Figure 6, A and B). Similarly, activation of these intracellular molecules was also observed in AT II epithelial cells by flow cytometry in isolated lung cells except activation of $\mathrm{pNF}-\kappa \mathrm{B}$, compared with untreated ones in CCSP-rtTA/(tetO) $)_{7}$-CMV-Stat3C bitransgenic mice (Figure 6, C and D). Therefore, both migrating inflammatory cells and residential epithelial cells contribute to oncogenesis in response to the microenvironment change. 
A
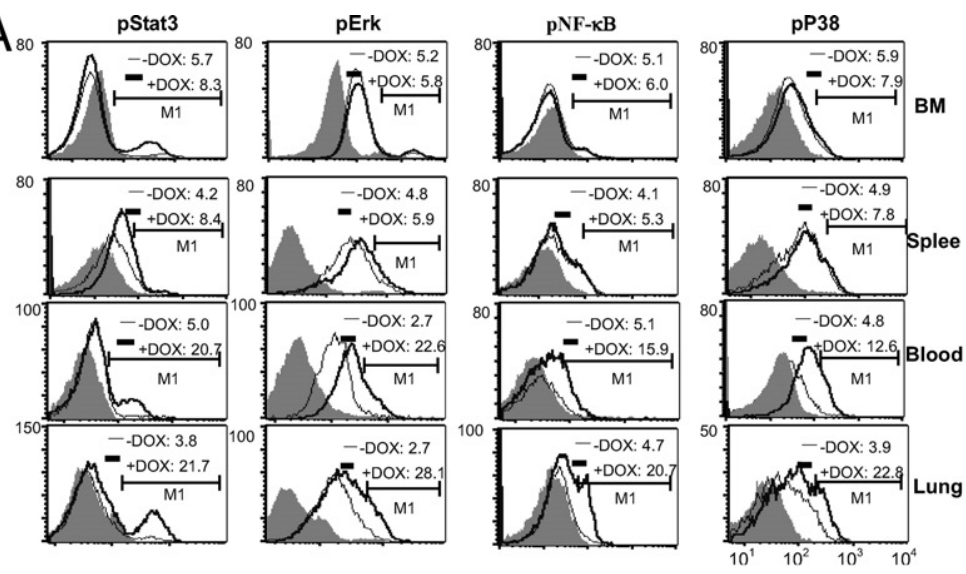

B
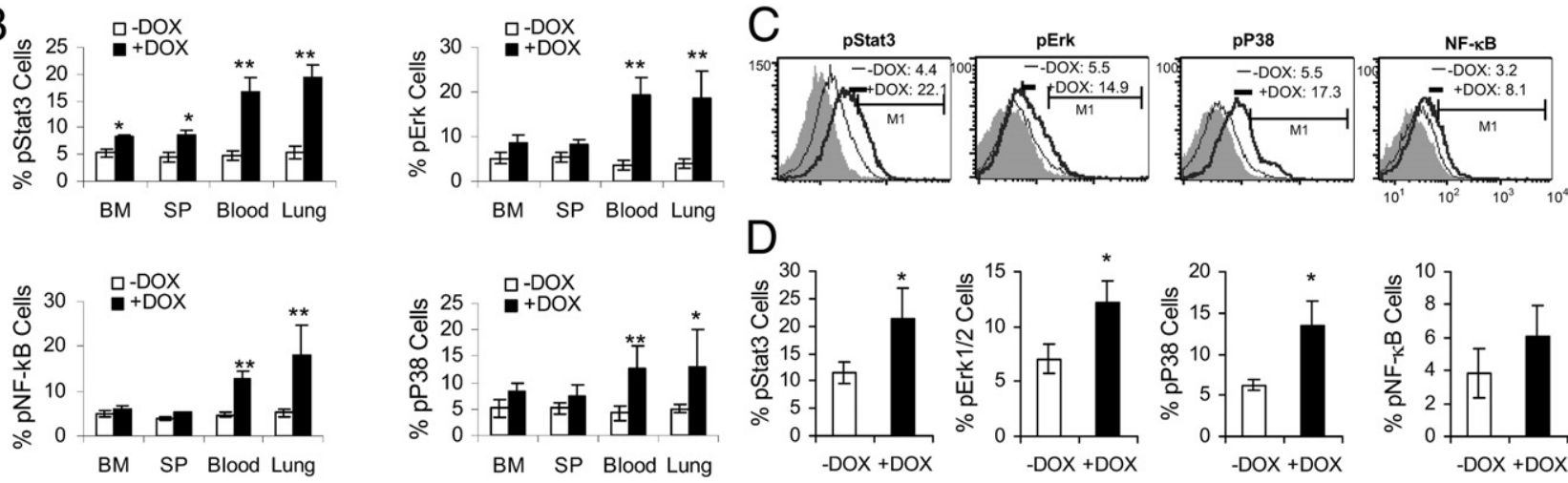

Figure 6. Activation of intracellular signaling molecules in MDSCs. A: Analysis of pStat 3 , pErk, pNF- $\kappa \mathrm{B}$, and pP38 in CD11b+Gr-1+ cells from blood and lung of 6-month doxycycline-treated or untreated bitransgenic mice in a representative experiment. Shaded areas are isotype control. B: The percentages of pStat3, pErk, pNF- $\kappa \mathrm{B}$, and pP38 in CD11b+Gr-1+ cells from blood and lung of 6-month doxycycline-treated or untreated bitransgenic mice $(n>4)$ were analyzed by flow cytometry. C: Analysis of pStat3, pErk, and pP38 in ATII epithelial cells of 6-month doxycycline-treated or untreated bitransgenic mice in a representative experiment. Shaded areas are isotype control. D: The percentages of pStat 3 , pErk, pNF- $\kappa \mathrm{B}$, and pP38 in ATII epithelial cells of 6-month doxycycline-treated or untreated bitransgenic mice $(n>4)$ were analyzed by flow cytometry. BM, bone marrow; -DOX, doxycycline-untreated bitransgenic mice; +DOX, doxycycline-treated bitransgenic mice; SP, spleen. ${ }^{*} P<0.05$; ${ }^{* * *} P<0.01$
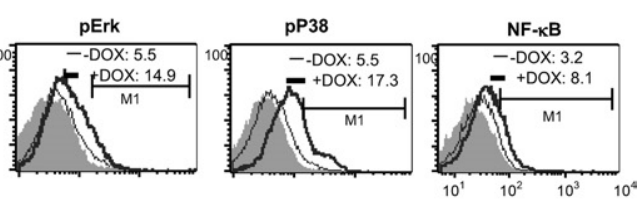

In Vitro CD11 $b^{+} \angle y 6 G^{+}$Cell Suppression on

Wild-Type T-Cell Proliferation and Response in CCSP-rtTA(tetO) $)_{7}$-CMV-Stat3C Bitransgenic Mice

To measure the effect of $\mathrm{CD} 11 \mathrm{~b}^{+} \mathrm{Ly}_{6 \mathrm{G}}{ }^{+}$cells on T-cell proliferation and response, $\mathrm{CD} 11 \mathrm{~b}^{+} \mathrm{Ly}_{6 \mathrm{G}}{ }^{+}$cells and $\mathrm{T}$-cell coculture studies were performed. $\mathrm{CD} 4^{+}$splenic $\mathrm{T}$ cells were isolated from 3-month-old wild-type mice, and CD11 $\mathrm{b}^{+}$ $\mathrm{Ly}_{6 \mathrm{G}}{ }^{+}$cells were isolated from lung of 6-month doxycycline-treated or untreated mice. Cocultured cells were stimulated with anti-CD3 mAb and anti-CD28 mAb for 4 days. T-cell proliferation was measured by carboxyfluorescein diacetate succinimidyl diester labeling dilution. T cell receptor (TCR) stimulated T-cell proliferation in the absence of CD11 $\mathrm{b}^{+} \mathrm{Ly}_{6 \mathrm{G}}{ }^{+}$cells (represented by multiple peaks, positive control, in Figure 7A). CD11 b ${ }^{+}{\text {Ly } 6 G^{+}}^{+}$cells from doxycycline-untreated bitransgenic mice slightly inhibited T-cell proliferation, whereas $\mathrm{CD} 11 \mathrm{~b}^{+} \mathrm{Ly}_{6 \mathrm{G}^{+}}$cells from doxycycline-treated bitransgenic mice completely abolished T-cell proliferation. In the PBS negative control group, no proliferation was observed. In addition, cell surface proliferating marker CD69 expression was elevated to approximately $75 \%$ on $\mathrm{CD}^{+}{ }^{+} \mathrm{T}$ cells when cocultured with $\mathrm{CD} 11 \mathrm{~b}^{+} \mathrm{Ly}_{6 \mathrm{G}^{+}}$ cells from lung of doxycycline-untreated bitransgenic mice after 48 hours stimulation with anti-CD3 Ab plus anti-CD28 $\mathrm{Ab}$. In contrast, expression of $\mathrm{CD} 69$ on $\mathrm{CD} 4^{+} \mathrm{T}$ cells was reduced to $60 \%$ on $\mathrm{CD}^{+}{ }^{+} \mathrm{T}$ cells when cocultured with $\mathrm{CD} 11 \mathrm{~b}^{+} \mathrm{Ly}_{6 \mathrm{G}^{+}}$cells from lung of doxycycline-treated mice (Figure 7B). No CD69 expression was observed in the PBS control group. CD11 b ${ }^{+} \mathrm{Ly}_{6 \mathrm{G}}{ }^{+}$cells isolated from bone mar- row and spleen of bitransgenic mice showed no obvious inhibition on CD69 expression, regardless of doxycycline treatment (Figure 7B).

Inhibition of T-cell proliferation was further supported by evidence that $C D 11 b^{+} L_{6} 6 G^{+}$cells from lung of doxycycline-treated mice increased $\mathrm{CD} 4^{+} \mathrm{T}$-cell apoptosis, compared with the doxycycline-untreated $C D 11 b^{+} L^{2} 6 G^{+}$cells (Figure $7 C$ ). To further evaluate the effect of $\mathrm{CD} 11 \mathrm{~b}^{+} \mathrm{Ly}_{6 \mathrm{G}}{ }^{+}$ cells on T-cell functional response, secretion of lymphokines was assessed by ELISA. CD4 ${ }^{+} T$ cells cocultured with MDSCs from lung of doxycycline-treated mice showed reduced secretion of IL-2 and IL-4 after TCR activation, compared with those of doxycycline-untreated CD11 $\mathrm{b}^{+} \mathrm{Ly}_{6 \mathrm{G}}{ }^{+}$ cells (Figure 7D). These observations indicate that

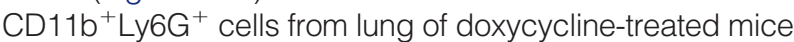
suppress proliferation and function of $\mathrm{CD} 4^{+} \mathrm{T}$ cells. Activation of lung $\mathrm{CD}_{11 \mathrm{~b}^{+} \mathrm{Ly} 6 \mathrm{G}^{+}}$cells in doxycycline-treated CCSP-rtTA/(tetO)7-CMV-Stat3c mice was further confirmed by up-regulation of arginase 1, inducible nitric oxide synthase, and $\mathrm{S} 100 \mathrm{~A}$ expression in lung $\mathrm{CD} 11 \mathrm{~b}^{+} \mathrm{Ly}_{6 \mathrm{G}}{ }^{+}$cells (Figure 7, E and F), given that these are important molecules regulating MDSC immunosuppressive function. ${ }^{17-19}$

\section{Discussion}

Multiple transgenic mouse models demonstrate that AT II epithelial cells serve as progenitor cells for lung adenocarcinoma when various oncogenic molecules are overexpressed in AT II epithelial cells., ${ }^{1,20-22}$ Activation of Stat3 by phosphorylation at Y705 is commonly observed 
A

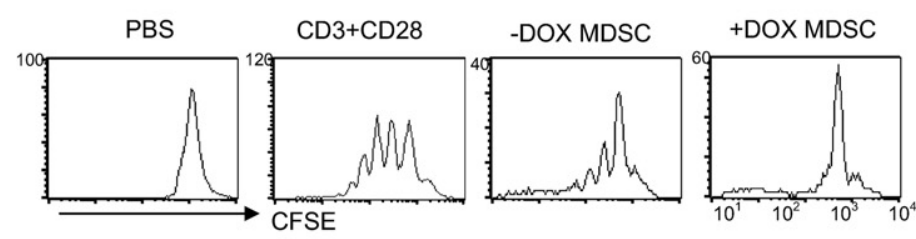

C

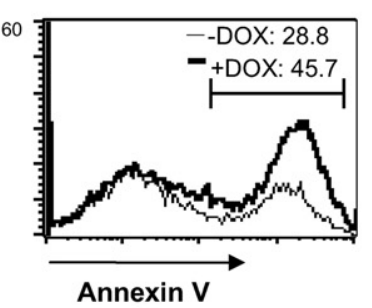

$E$

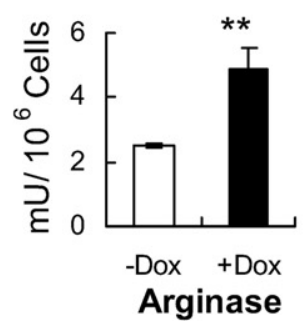

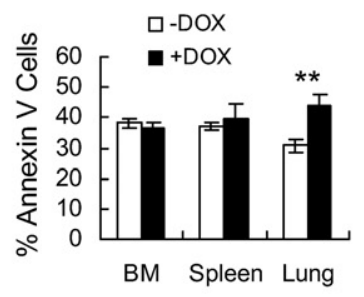

$\mathrm{F}$

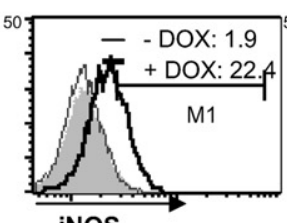

iNOS
B
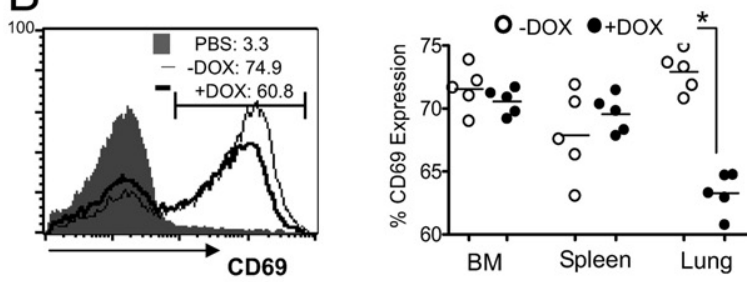

D

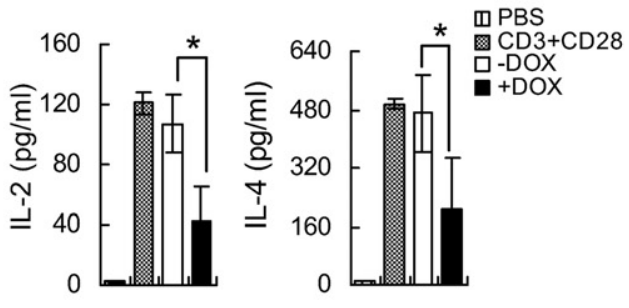

Lung CD11b+Ly-6G+

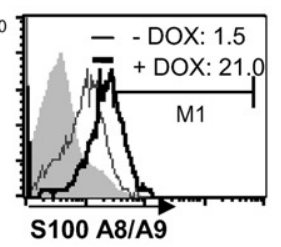

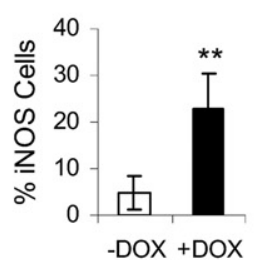

Figure 7. The suppressive function of MDSCs on wild-type splenic CD $4^{+} \mathrm{T}$ cells in the coculture study. Splenic CD $4^{+} \mathrm{T}$ cells from 3 -month-old wild-type mice were cocultured with MDSCs from 6-month doxycycline-treated or untreated bitransgenic mice. The ratio of MDSCs:CD4 ${ }^{+}$T cells was 1:5. A: Inhibition of CD $4^{+}$ T-cell proliferation was analyzed by carboxyfluorescein diacetate succinimidyl diester (CFSE) labeling and flow cytometry. One representative of five experiments is shown. B: A representative flow cytometry analysis shows decreased CD $69^{+}$expression on splenic $\mathrm{CD} 4^{+} \mathrm{T}$ cells. The frequency of $\mathrm{CD} 69^{+}$expression was statistically analyzed (mice, $n=5$ ). C: Splenic CD $4^{+}$T-cell apoptosis was analyzed by annexin V labeling $(n=5)$. D: Lymphokine production by splenic CD $4^{+}$ T cells in coculturing medium was determined by ELISA (mice, $n=5$ ). E: Arginase I activity in BALF cells from 9-month doxycycline-treated or untreated bitransgenic mice $(n=5)$. F: Expression levels of inducible nitric oxide synthase (iNOS) and S100A8/A9 were determined by flow cytometry from 6-month doxycycline-treated or untreated bitransgenic mice $(n=5)$. BM, bone marrow; - DOX, doxycycline-untreated bitransgenic mice; + DOX, doxycycline-treated bitransgenic mice; SP, spleen. ${ }^{*} P<0.05 ;{ }^{* *} P<0.01$.

in these models. Of note, we recently reported that lung adenocarcinoma caused by overexpression of apoptotic inhibitor 6 in myeloid cells also shows Stat3 phosphorylation at Y705 in AT II epithelial cells. ${ }^{3}$ Thus, activation of the Stat3 pathway is a critical step leading toward lung adenocarcinoma. This concept has been directly proven in a CCSP-rtTA/(tetO) $)_{7}$-CMV-Stat3C bitransgenic mouse model in which persistent activation of the Stat3 pathway by overexpressing Stat3C in AT II epithelial cells leads to lung adenocarcinoma. ${ }^{1}$ The formation of lung adenocarcinoma is a complex process that involves cancerous transformation of epithelial cells by reactivation of developmental programs, ${ }^{23}$ introduction of mutations causing genetic instability, ${ }^{24}$ and epigenetic changes. ${ }^{25}$ Under normal physiological conditions, spontaneous cancerous transformation is constantly monitored by the immune surveillance system, which destroys any transformed cells that impose danger to the body. Under tumor pathological conditions, however, the immune surveillance system is scrambled and no longer recognizes or is unable to destroy tumor cells. Understanding of the molecular and cellular pathways that cause this immune abnormality is needed.

Because Stat3 plays a key role in inflammation-induced tumorigenesis, ${ }^{26,27}$ the CCSP-rtTA/(tetO) $)_{7}-\mathrm{CMV}$ -
Stat3C bitransgenic mouse model is well suited to depict inflammatory pathways in lung adenocarcinoma formation. Stat3 is a potent transcription factor that mediates proinflammatory IL-6 family cytokines. An oncogenic Stat3C has been designed to mimic the action of activated Stat3. ${ }^{28}$ In this molecule, substitution of two cysteine residues within the C-terminal loop of the $\mathrm{SH} 2$ domain of Stat3 produces a molecule that dimerizes spontaneously. Based on our previous study, Stat3C overexpression in AT II epithelial cells changes expression levels of approximately 800 downstream genes as demonstrated by GeneChip microarray analysis. ${ }^{1}$ Among these genes, a group of proinflammatory cytokines and chemokines are highly up-regulated at the very early stage (1-month doxycycline treatment) in AT II epithelial cells. ${ }^{1}$ ELISA analysis confirmed secretion of GM-CSF, IFN- $\gamma$, IL-1 $\beta$, IL-6, IL-10, IL-13, and TNF- $\alpha$ into the alveolar lumen and blood of doxycycline-treated bitransgenic mice (Figure 4). These soluble factors are well known for their functions in recruiting and accumulating MDSCs in cancer conditions. ${ }^{7-9}$ Up-regulation of these cytokines may serve as biomarkers for lung cancer prediction. It has been reported that tumor Stat3 activity promotes production of VEGF and IL-10. ${ }^{29}$ Ablating Stat3 in hema- 
topoietic cells triggers an intrinsic immune-surveillance system that inhibits tumor growth and metastasis. ${ }^{30}$

We previously identified inflammatory cell infiltration in tumor areas of CCSP-rtTA/(tetO) $)_{7}$-CMV-Stat3C bitransgenic mice. ${ }^{1}$ How these cells contribute to tumor formation is not known. We therefore designed a study to examine $\mathrm{CD} 11 \mathrm{~b}^{+} \mathrm{Gr}-1^{+}$cells in various organs of CCSP-rtTA/(tetO) $7_{7^{-}}$ CMV-Stat3C bitransgenic mice. CD11 b ${ }^{+}{\text {Ly } 6 G^{+}}^{+}$and CD11 $b^{+}$ $\mathrm{Ly}_{6} \mathrm{C}^{+}$cell populations were highly elevated in lung and blood of doxycycline-treated bitransgenic mice, but not in bone marrow and spleen (Figure 2). This differs from observations in lysosomal acid lipase knockout mice and c-fms-rtTA/(tetO) $)_{7}$-CMV-MMP12 bitransgenic mice that cause systemic inflammation and pathogenic phenotypes, as we recently reported, in which $\mathrm{CD} 11 \mathrm{~b}^{+} \mathrm{Ly} 6 \mathrm{G}^{+}$cells show systemic expansion, including bone marrow, spleen, blood, and lung. ${ }^{4,31}$ In those animal models, CD11 ${ }^{+}$ $\mathrm{Ly} 6 \mathrm{G}^{+}$cell expansion is mainly caused by abnormal hematopoietic development, differentiation, and myelopoiesis.

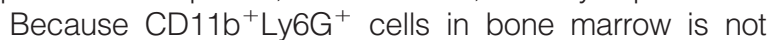
affected in CCSP-rtTA/(tetO) $)_{7}$-CMV-Stat3C bitransgenic mice, a different mechanism must contribute to CD11 ${ }^{+}$ $\mathrm{Ly}_{6 \mathrm{G}^{+}}$cell expansion in lung and blood. Importantly, the BALF treatment study suggests that $C D 11 b^{+} L^{2} 6 G^{+}$cell malformations come primarily from conversion of alveolar monocytes/macrophages (Figure 5A). This is consistent with our observation of increased elevation of MDSC-stimulating cytokines in BALF of Stat3C-overexpressing mice (Figure 4). When tested in vitro, these cytokines show differential abilities in converting different subpopulations of $\mathrm{CD} 11 \mathrm{~b}^{+} \mathrm{Gr}-1^{+}$cells from alveolar monocytes/macrophages (Figure 5). $\mathrm{CD}_{11 \mathrm{~b}^{+} \mathrm{Gr}-1^{+}}$cells from both $\mathrm{lal}{ }^{-1-}$ and CCSPrtTA/(tetO) $)_{7}-\mathrm{CMV}-\mathrm{Stat} 3 \mathrm{C}$ animal models show similar intrinsic changes, in which activation of intracellular molecules (eg, Stat3, Erk, p38, NF- $\kappa$ B) is increased (Figure 6, A and B). ${ }^{31}$ The same observation was made also in AT II epithelial cells in doxycycline-treated CCSP-rtTA/(tetO) ${ }_{7}-\mathrm{CMV}$-Stat3C bitransgenic mice (Figure 6, C and D). These findings indicate that these oncogenic molecules not only participate in AT II epithelial cell to cancerous cell transformation, but also sustain $\mathrm{CD} 11 \mathrm{~b}^{+} \mathrm{Gr}-1^{+}$cell expansion.

Molecules that regulate T-cell suppression such as arginase 1 , inducible nitric oxide synthase, and S100A are also up-regulated in lung $\mathrm{CD} 11 \mathrm{~b}^{+} \mathrm{Ly}_{6 \mathrm{G}}{ }^{+}$cells (Figure $7, \mathrm{E}$ and $\mathrm{F}$ ). Functionally, $\mathrm{CD} 11 \mathrm{~b}^{+} \mathrm{Gr}-1^{+}$cells from lung of doxycycline-treated CCSP-rtTA/(tetO) $)_{7}-\mathrm{CMV}$ Stat3C bitransgenic mice show a much stronger inhibitory activity on wild-type T-cell proliferation, CD69 expression, and T-cell lymphokine release on TCR stimulation than those from untreated littermates (Figure 7). Notably, T-regulatory cells are increased also in doxycycline-treated CCSP-rtTA/(tetO) ${ }_{7}-\mathrm{CMV}$-Stat3C bitransgenic mice (Figure $3 \mathrm{C}$ ). It is known that T-regulatory cells inhibit $\mathrm{CD}^{+}{ }^{+}$T cells in cancer, ${ }^{32}$ and MDSCs mediate development of tumor-induced T-regulatory cells. ${ }^{33}$ Taken together, abnormal CD11 $\mathrm{b}^{+} \mathrm{Gr}-1^{+}$cells and T-regulatory cell expansion contribute to immunosuppression on $\mathrm{T}$ cells in lung of Stat3C-overexpressing bitransgenic mice (Figure 3). It is possible that impaired $T$ cells lack a normal response to attack tumor cells in bitransgenic mice.
In conclusion, we report here that $\mathrm{CD} 11 \mathrm{~b}^{+} \mathrm{Gr}-1^{+}$cells with MDSCs play a critical role in Stat3-induced chronic inflammation and may participate in lung tumorigenesis by enhancing immune suppression on T cells for tumor growth. Therefore, suppressing CD $11 \mathrm{~b}^{+} \mathrm{Gr}-1^{+} \mathrm{MDSC}$ accumulation and activity is essential for treating inflammation-induced lung cancer. The findings presented here indicate that Stat3 is a master molecule to promote $\mathrm{CD} 11 \mathrm{~b}^{+} \mathrm{Gr}-1^{+}$MDSC expansion by controlling synthesis and secretion of proinflammatory cytokines and chemokines. Understanding of the molecular and cellular mechanisms outlined here may lead to new ways to block proinflammatory molecules and related pathways, to reduce lung cancer incidence.

\section{Acknowledgments}

We thank Beilin Li for animal maintenance and Dr. Peng Qu for technical assistance.

\section{References}

1. Li Y, Du H, Qin Y, Roberts J, Cummings OW, Yan C: Activation of the signal transducers and activators of the transcription 3 pathway in alveolar epithelial cells induces inflammation and adenocarcinomas in mouse lung. Cancer Res 2007, 67:8494-8503

2. Qu P, Du H, Wang X, Yan C: Matrix metalloproteinase 12 overexpression in lung epithelial cells plays a key role in emphysema to lung bronchioalveolar adenocarcinoma transition. Cancer Res 2009, 69: 7252-7261

3. Qu P, Du H, Li Y, Yan C: Myeloid-specific expression of Api6/AIM/Sp alpha induces systemic inflammation and adenocarcinoma in the lung. J Immunol 2009, 182:1648-1659

4. Qu P, Yan C, Du H: Matrix metalloproteinase 12 overexpression in myeloid lineage cells plays a key role in modulating myelopoiesis, immune suppression, and lung tumorigenesis. Blood 117:4476-4489

5. Qu P, Roberts J, Li Y, Albrecht M, Cummings OW, Eble JN, Du H, Yan C: Stat3 downstream genes serve as biomarkers in human lung carcinomas and chronic obstructive pulmonary disease. Lung Cancer 2009, 63:341-347

6. Barbieri I, Pensa S, Pannellini T, Quaglino E, Maritano D, Demaria M, Voster A, Turkson J, Cavallo F, Watson CJ, Provero P, Musiani P, Poli $\checkmark$ : Constitutively active Stat3 enhances neu-mediated migration and metastasis in mammary tumors via upregulation of Cten. Cancer Res 70:2558-2567

7. Gabrilovich D: Mechanisms and functional significance of tumourinduced dendritic-cell defects. Nat Rev Immunol 2004, 4:941-952

8. Ostrand-Rosenberg S, Sinha P: Myeloid-derived suppressor cells: linking inflammation and cancer. J Immunol 2009, 182:4499-4506

9. Sica A, Bronte V: Altered macrophage differentiation and immune dysfunction in tumor development. J Clin Invest 2007, 117:1155-1166

10. Youn JI, Nagaraj S, Collazo M, Gabrilovich DI: Subsets of myeloidderived suppressor cells in tumor-bearing mice. J Immunol 2008, 181:5791-5802

11. Movahedi K, Guilliams M, Van den Bossche J, Van den Bergh R, Gysemans C, Beschin A, De Baetselier P, Van Ginderachter JA: Identification of discrete tumor-induced myeloid-derived suppressor cell subpopulations with distinct $T$ cell-suppressive activity. Blood 2008, 111:4233-4244

12. Qu P, Du H, Wilkes DS, Yan C: Critical roles of lysosomal acid lipase in T cell development and function. Am J Pathol 2009, 174:944-956

13. Corraliza IM, Campo ML, Soler G, Modolell M: Determination of arginase activity in macrophages: a micromethod. J Immunol Methods 1994, 174:231-235

14. Peranzoni E, Zilio S, Marigo I, Dolcetti L, Zanovello P, Mandruzzato S, Bronte V: Myeloid-derived suppressor cell heterogeneity and subset definition. Curr Opin Immunol 22:238-244 
15. Balkwill F: Cancer and the chemokine network. Nat Rev Cancer 2004 4:540-550

16. Yang L, DeBusk LM, Fukuda K, Fingleton B, Green-Jarvis B, Shyr Y, Matrisian LM, Carbone DP, Lin PC: Expansion of myeloid immune suppressor $\mathrm{Gr}+\mathrm{CD} 11 \mathrm{~b}+$ cells in tumor-bearing host directly promotes tumor angiogenesis. Cancer Cell 2004, 6:409-421

17. Cheng P, Corzo CA, Luetteke N, Yu B, Nagaraj S, Bui MM, Ortiz M, Nacken W, Sorg C, Vogl T, Roth J, Gabrilovich DI: Inhibition of dendritic cell differentiation and accumulation of myeloid-derived suppressor cells in cancer is regulated by S100A9 protein. J Exp Med 2008, 205:2235-2249

18. Rodríguez PC, Ochoa AC: Arginine regulation by myeloid derived suppressor cells and tolerance in cancer: mechanisms and therapeutic perspectives. Immunol Rev 2008, 222:180-191

19. Condamine T, Gabrilovich DI: Molecular mechanisms regulating myeloid-derived suppressor cell differentiation and function. Trends Immunol 32:19-25

20. Politi K, Zakowski MF, Fan PD, Schonfeld EA, Pao W, Varmus HE: Lung adenocarcinomas induced in mice by mutant EGF receptors found in human lung cancers respond to a tyrosine kinase inhibitor or to down-regulation of the receptors. Genes Dev 2006, 20:1496-1510

21. Engelman JA, Chen L, Tan X, Crosby K, Guimaraes AR, Upadhyay R, Maira M, McNamara K, Perera SA, Song Y, Chirieac LR, Kaur R, Lightbown A, Simendinger J, Li T, Padera RF, García-Echeverría C, Weissleder R, Mahmood U, Cantley LC, Wong KK: Effective use of PI3K and MEK inhibitors to treat mutant Kras G12D and PIK3CA H1047R murine lung cancers. Nat Med 2008, 14:1351-1356

22. Fisher GH, Wellen SL, Klimstra D, Lenczowski JM, Tichelaar JW, Lizak MJ, Whitsett JA, Koretsky A, Varmus HE: Induction and apoptotic regression of lung adenocarcinomas by regulation of a K-Ras transgene in the presence and absence of tumor suppressor genes. Genes Dev 2001, 15:3249-3262

23. Borczuk AC, Gorenstein L, Walter KL, Assaad AA, Wang L, Powell CA: Non-small-cell lung cancer molecular signatures recapitulate lung developmental pathways. Am J Pathol 2003, 163:1949-1960
24. Ding L, Getz G, Wheeler DA, Mardis ER, McLellan MD, Cibulskis K, et al: Somatic mutations affect key pathways in lung adenocarcinoma. Nature 2008, 455:1069-1075

25. Toyooka S, Tokumo M, Shigematsu H, Matsuo K, Asano H, Tomii K, Ichihara S, Suzuki M, Aoe M, Date H, Gazdar AF, Shimizu N: Mutational and epigenetic evidence for independent pathways for lung adenocarcinomas arising in smokers and never smokers. Cancer Res 2006, 66:1371-1375

26. Jarnicki A, Putoczki T, Ernst M: Stat3: linking inflammation to epithelial cancer - more than a "gut" feeling? Cell Div 5:14

27. Yu H, Pardoll D, Jove R: STATs in cancer inflammation and immunity: a leading role for STAT3. Nat Rev Cancer 2009, 9:798-809

28. Bromberg JF, Wrzeszczynska MH, Devgan G, Zhao Y, Pestell RG, Albanese C, Darnell JE Jr: Stat3 as an oncogene [Erratum appeared in Cell 1999, 99:239]. Cell 1999, 98:295-303

29. Wang T, Niu G, Kortylewski M, Burdelya L, Shain K, Zhang S, Bhattacharya R, Gabrilovich D, Heller R, Coppola D, Dalton W, Jove R, Pardoll D, Yu H: Regulation of the innate and adaptive immune responses by Stat-3 signaling in tumor cells [Erratum appeared in Nat Med 2004, 10:209]. Nat Med 2004, 10:48-54

30. Kortylewski M, Kujawski M, Wang T, Wei S, Zhang S, Pilon-Thomas S, Niu G, Kay H, Mulé J, Kerr WG, Jove R, Pardoll D, Yu H: Inhibiting Stat3 signaling in the hematopoietic system elicits multicomponent antitumor immunity. Nat Med 2005, 11:1314-1321

31. Qu P, Shelley WC, Yoder MC, Wu L, Du H, Yan C: Critical roles of lysosomal acid lipase in myelopoiesis. Am J Pathol 2010, 176:23942404

32. Wang HY, Wang RF: Regulatory T cells and cancer. Curr Opin Immunol 2007, 19:217-223

33. Huang B, Pan PY, Li Q, Sato Al, Levy DE, Bromberg J, Divino CM, Chen SH: Gr-1+CD115+ immature myeloid suppressor cells mediate the development of tumor-induced $\mathrm{T}$ regulatory cells and T-cell anergy in tumor-bearing host. Cancer Res 2006, 66:11231131 